\title{
Managing founder-based brand identity during succession
}

This is the peer reviewed version of the following article:

Original:

Casprini, E., Melanthiou, Y., Pucci, T., Zanni, L. (2020). Managing founder-based brand identity during succession. JOURNAL OF BRAND MANAGEMENT, 27, 1-14 [10.1057/s41262-019-00161-x].

Availability:

This version is availablehttp://hdl.handle.net/11365/1075714 since 2021-03-24T13:06:24Z

\section{Published:}

DOI:10.1057/s41262-019-00161-x

Terms of use:

Open Access

The terms and conditions for the reuse of this version of the manuscript are specified in the publishing policy. Works made available under a Creative Commons license can be used according to the terms and conditions of said license.

For all terms of use and more information see the publisher's website.

(Article begins on next page) 


\section{TITLE: MANAGING FOUNDER-BASED BRAND IDENTITY DURING SUCCESSION}

\section{SHORT RUNNING TITLE: MANAGING FOUNDER-BASED BRAND IDENTITY}

AUTHORS: Elena Casprini, Yioula Melanthiou, Tommaso Pucci, Lorenzo Zanni

\section{SHORT BIO:}

ELENA CASPRINI is a Postdoctoral Researcher in Management at Department of Business and Law, University of Siena (Siena, Italy). She obtained her Ph.D. at Scuola Superiore Sant'Anna (Pisa, Italy). She has been a Visiting Ph.D. at Cass Business School (London, UK). She is involved in academic and research activities at bachelor and master levels. Her main research interests are regarding business model innovation, open innovation and family firms.

YIOULA MELANTHIOU is an Associate Professor at the University of Nicosia, holds a BA in Business Administration (Marketing Major), an MSc in Marketing (University of Salford, UK), and a PhD in Marketing (University of Manchester, UK). Since joining the University of Nicosia in 2004, she has been teaching several marketing courses at an undergraduate and postgraduate level. Her primary research interests are in the areas of Social Media Marketing, Consumer Behaviour and Marketing of Higher Education.

TOMMASO PUCCI is an assistant professor in management and marketing at the Department of Business and Law, University of Siena (Siena, Italy). He obtained his Ph.D. in Economics and Management of Enterprises and Local Systems at University of Florence (Florence, Italy). His research interests include Management, Innovation Management, Management and Marketing of "Made in Italy", International Business.

LORENZO ZANNI is a full Professor of Economics and Business Management at the Department of Business and Law, University of Siena. His research interests are in the fields of: small businesses and entrepreneurship, economics and management of innovation, international management and marketing. At the moment, he is vice-chancellor for technology transfer and university-industry relations at the University of Siena.

\section{CONTACT DETAILS OF THE CORRESPONDING AUTHOR:}

Elena Casprini

Department of Business and Law, University of Siena piazza San Francesco 8, 53100 Siena (Italy)

Ph. nr.: (+39) 0577232659

Fax: (+39) 0577232880

E-mail: elena.casprini@unisi.it 


\section{MANAGING FOUNDER-BASED BRAND IDENTITY DURING SUCCESSION}

Keywords: brand identity, family firm, succession

\section{Introduction}

Among the unique resources that family firms (FFs) possess, brand identity (BI) can be a key driver in defining their competitiveness. In fact, FFs often deliberately choose to promote their products alongside their family name, in order to describe their family history and emphasise their long-lasting traditions and reputation. Examples such as the Portuguese Camuffo (since 1438) for shipbuilding and the Italian Barone Ricasoli (since 1141) for wine, are well known FFs recognized for their high-quality products, traditions, and reliability.

Research on family-based BI is still in its infancy. FFs tend to adopt different strategies in communicating their BI offline and online (Blombäck and Ramírez- Pasillas, 2012; Micelotta and Raynard, 2011). Most of this literature, however, has only focused on examining whether family-based communication strategies have an impact on the firm's performance (Craig, Dibrell, and Davis, 2008), whether family-owned firms are perceived more positively by customers than their non-family counterparts (Binz et al. 2013), and on how FFs communicate their family identity on their websites (Botero et al., 2013). 
What remains unclear is how a FF creates and shapes its BI over time. Identity is not a static concept; it emerges over time and is considered to be one of the key characteristics that distinguish family from non-FFs, since the identity of a FF may change with the succession from a former generation to the next. How BI is managed over time, and specifically during succession, appears to be an unexplored topic.

The succession process has increasingly attracted attention from scholars of FFs (Churchill and Hatten, 1987; Hauck and Prügl, 2015; Kansikas and Nemilentsev 2010; Marler, Botero and De Massis, 2016), but its influence on marketing-related concepts has not been investigated in depth. During succession, a family-based BI might be influenced by the advent of the next generation that could shape the vision and the culture of the FF, adopt different branding strategies, and involve different stakeholders. This becomes even more complex when the family-based identity is not only linked to the family name, but it is linked with the founder's name (founder-based BI). Examples of this type are much rarer, but still important, especially in sectors such as fashion for instance, where the founder is also the designer - e.g. Salvatore Ferragamo. Consequently, when founder-based BI is one of the key strategic resources of the $\mathrm{FF}$, being able to preserve it is the challenge for the next generation.

Drawing from the resource-based view of the firm and adopting Urde's (2013) BI framework that distinguishes between internal, both internal and external (core), or external elements, the aim of this paper is to explore how FFs manage their founder-based BI during succession. An exploratory case study conducted on an Italian FF operating in the jewellery sector, Argenterie Giovanni Raspini s.p.a., revealed that the FF manages its founder-based BI by preserving and adapting processes that mainly result from a juxtaposition of the first and the second generations, but also of the non-family members.

Linking brand management and FF literatures, focusing on the intersection between BI and succession, the paper makes two main contributions. First, it introduces the concept of 
"founder-based BI", thus closely looking at the heterogeneity of family-based branding strategies. Second, it provides an in-depth description of how a FF manages its BI during succession, thus providing an example for those FFs facing the same challenge.

The paper is structured as follows. In Section 2, we provide a literature review on BI, BI in FFs, and succession. Then, after an overview of the data collection and analysis (Section 3), we examine how Argenterie Giovanni Raspini s.p.a, has managed and is managing its founderbased BI, focusing on the role of the second generation (Section 4). Finally, after a discussion of the emerging framework for managing BI, the limitations and implications for theory and practice are presented (Section 5).

\section{Theoretical background}

\subsection{Brand Identity}

It is very important to define what we mean by BI. The concept of identity, in fact, lacks construct clarity (Cornelissen, Christensen, and Kinuthia, 2012; Urde, 2013), spanning multiple levels of analysis, such as the individual, group, organizational and cultural levels (Brown, Dacin, Pratt and Whetten, 2006; Cornelissen, Haslam, and Balmer, 2007) and multiple disciplines (Balmer, 2001; Cornelissen et al., 2007). For example, previous research on organizations and marketing has tended to distinguish between organizational identity and (corporate) BI as being different, but interrelated elements (Balmer and Burghausen, 2015; Blombäck and Ramírez- Pasillas, 2012; Cornelissen et al., 2007).

Traditionally, BI has been defined as "a unique set of brand associations that the brand strategist aspires to create and maintain" (Aaker, 1996: 68), made up of several elements (da Silveira, Lages, and Simões 2013; Kapferer 2012; Muhonen, Hirvonen, and Laukkanen 2017). For example, de Chernatony (1999) proposes a model of BI "in terms of its vision and culture, 
which drive its desired positioning, personality and the subsequent relationships" (p. 166). Similarly, Muhonen et al. (2017) distinguish three main components of BI, namely brand values, brand vision and brand positioning. As Blombäck and Ramírez- Pasillas (2012) note "BI is commonly materialized through, but not limited to, the corporate name, market offer, logotypes, slogans, employee behaviour, and different forms of planned communication [...] provides a link between a company and its stakeholders" (2012: 8). Essentially, a BI refers to how a firm wants others to regard it and is the result of multiple elements that are somehow carefully managed through a planned communication. A useful framework describing the element of BI is provided by Urde (2013) who identified nine elements of corporate BI. These include the core identity which is represented by the promises and core values, as well as the internal, external and internal-external (expression and personality) elements which represent the extended identity.

BI has been mainly investigated from a static point of view. However, more recently, it has been noted that BI is dynamic and can be co-created by multiple stakeholders (Melewar, Nguyen, Alwi, and Navare, 2017; Michel, 2017; von Wallpach, Voyer, Kastanakis, and Mühlbacher, 2017). In fact, “BI is a dynamic concept that originates among brand managers, and that further develops through mutually influencing inputs from managers and other social constituents; this development involves distinguishing, central, and enduring attributes, where enduring takes a dynamic meaning - core values maintain consistency over time while other dimensions vary, when needed, to adjust to the environmental context" (da Silveira, Lages, and Simões 2013: 33). For example, da Silveira et al. (2013) look at the role of managers in reshaping BI according to environmental changes and consumers. 


\subsection{Brand identity in family firms}

FFs possess multiple identities (Botero et al., 2013). However, most previous research has focused on FF organizational identity (Zellweger, Eddleston, and Kellermanns, 2010), on the distinction among actual, conceived, communicated, ideal and desired FF identity (Botero et al., 2013) or, more broadly, on the FF image (Zellweger, Kellermanns, Eddleston, and Memili, 2012). Research into BI in FFs is still in its infancy (Beck, 2016; Binz Astrachan, Botero, Astrachan and Prügl, 2018).

A family BI has been defined as "the consistent and targeted representations of the organization in its managed communication with external stakeholders" (Micelotta and Raynard, 2011:198). This definition stresses two main parts: first, the FF chooses what message to communicate. Presas, Muños and Guia (2011) look at the creation of a family corporate brand. Drawing on Hatch and Schultz (2001), these authors focus on the FF brand as being derived from the interaction of three elements which are the strategic vision (i.e. what the firm aims to achieve in the long term), the organizational culture (i.e. values, beliefs and premises to be communicated to internal stakeholders) and the corporate image (i.e. how stakeholders regard the firm). Second, this message is transmitted in a managed way. FFs tend to communicate their BI with different strategies, such as family preservation, family enrichment and family subordination (Micelotta and Raynard, 2011). Branding strategies may communicate the family as a corporate brand or a product brand (Gallucci, Santulli, and Calabrò, 2015). For example, empirical research notes that family-based BI influences competitive orientation and firm performance and that "family-based BI positively contributes to firm performance indirectly, via a customer-centric orientation" (Craig, Dibrell, and Davis 2008). Other researchers have looked at the tools through which family BI can be communicated, such as the case of a corporate brand museum (Iannone and Izzo, 2017) or the case of a corporate heritage identity (Burghausen and Balmer, 2014). 
In addition, as Binz Astrachn, Botero, Astrachan and Prügl (2018) note, there are different components of a FF brand, namely the level of family promotion, the characterization of the owning family, the representation of the owning family, the communication channels used, the stakeholders addressed, the brand architecture, and the unpremeditated image.

\subsection{Succession in family firms}

Succession is one of the challenges for continuity of the FF (Hauck and Prügl, 2015; Kansikas and Nemilentsev 2010; Marler, Botero and De Massis, 2016; PwC 2017). Previous research has extensively discussed the factors that facilitate and/or hinder succession (Bizri, 2016) and both literature review (Brockhaus, 2004; Handler, 1994) and conceptual (Fox, Nilakant, and Hamilton, 1996) work have examined this theme.

What is consistent in previous studies is that succession should be seen as a process rather than a punctuated event. There are three main (and interlinked) streams of research in the succession-related literature. The first stream refers to the questions arising in the choice of the successor, and specifically with regards to the choice between a family or a non-family member. Succession dynamics may be influenced by several factors, such as conversations (Helin and Jabri, 2016) and idiosyncratic knowledge (Royer, Simons, Boyd, and Rafferty, 2008). For example, following on from transaction cost theory, Royer et al. (2008) propose a contingency model of FF succession on the basis of the industrial context in which a firm operates. Royer et al. (2008) further note that there are different types of knowledge (general, technical and idiosyncratic/specific knowledge), and thus a family member is preferable over an outsider when there is a high degree of experiential specific knowledge of the family business.

Another stream of research refers to how the succession process occurs. The life-cycle approach evidenced by Churchill and Hatten (1987) differentiates between two aspects of the transfer of control or power, namely the transfer of ownership and the transfer of management 
control. Marler, Botero and De Massis (2016) note that the transition role during and following succession is influenced by the congruence of the incumbent and the proactive personality of the successor, and on whether the incumbents are succession ready or not. When the incumbent and the successors are proactive, and the incumbent is succession ready, the transition role is more effective since there is a greater goal alignment and higher cooperation during the succession process.

Finally, the third stream of research looks at the impact of succession on FF performance. For example, Hauck and Prügl (2015) investigate how socio-emotional factors are related to the owner-managers' perception of the suitability of the intra-family leadership succession phase in terms of innovation activities. They found that the succession phase is perceived as a good opportunity for innovation when the family has a high level of adaptability and the family member is close to the FF, while intergenerational authority and the history of family bonds are negatively related to innovation.

The succession process is clearly highly complex and delicate to manage. Hence, the aim of this paper is to further explore the mechanisms underlying how a FF manages its founderbased BI during succession.

\section{Methodology}

This research adopted a single case study design (Yin, 2003), primarily because qualitative methods have been widely applied in FF research (Hair and Sarstedt, 2014; Wilson et al., 2014) and still remain important for answering "how" questions (De Massis and Kotlar, 2014; Yin, 2003). Our research was based on Argenterie Giovanni Raspini s.p.a., an Italian FF in the jewellery industry. The case was chosen for multiple reasons. First, the firm is a FF since it is " $a$ company that is owned or controlled by a family and in which one or more relatives is involved with management" (Lansberg and Astrachan 1994:39). Second, during the last six years the 
second generation has joined the firm, thus enabling us to explore how this has influenced the BI. Third, the research group has privileged access to firm data having collaborated with the firm for several years.

\subsection{Empirical setting}

Argenterie Giovanni Raspini s.p.a. was founded in 1985 and is nationally, and more recently internationally, recognized as an excellent silver-jewels manufacturer, known by its brand "Giovanni Raspini". Giovanni Raspini is both the brand and the name of the founder-designer, a sixty-year old man whose creativity and style have been embedded in his creations.

Since its foundation, the firm has grown slowly, but continuously, creating a unique BI whose core element is linked to the distinctive style, mainly inspired by nature and animals, emphasising the contrast between dark and light as characterised by the silver (or other derivatives, such as golden-silver or German silver), the Made in Italy brand, and the link with the local geographical area as well as the uniqueness derived from the craftsmanship.

Like many other firms, Argenterie Giovanni Raspini is continuously struggling in the market to reinforce its BI. Maintaining a distinctive BI in the jewellery industry, is in fact, a huge challenge, as it is characterized by low entry barriers and fierce competition. Especially for smaller firms that cannot afford large marketing investments, being able to differentiate themselves and to maintain this differentiation over time is particularly tricky.

Among the key elements used for differentiation, the name of the family has attracted increasing attention (Botero et al., 2013; Craig et al., 2008; Micelotta and Raynard, 2011). However, when the BI is linked not only to the family, but also to the founder's name, new challenges arise once the new generation joins. 


\subsection{Data collection and analysis}

Data were primarily collected by in-depth, face-to-face interviews with family- and non-family members between December 2016 and October 2017. In addition, other data were derived by direct observations from a visit to the firm by the first author together with secondary data sources, namely corporate presentations, corporate printed material, national press and corporate website. These data sources also allowed for data triangulation.

Eleven interviews were conducted with eight people. Two family members, the founder and his daughter, as well as one non-family member were interviewed twice. As with other studies on corporate identities (He and Balmer, 2013), we focused on senior managers since they contribute the most to the development of the organization's identity. Finally, we also interviewed younger collaborators and an external consultant who has worked twice a week for the FF since 2011.

We used these sources to: (i) understand the history of the firm; (ii) depict how the FF created its BI; (iii) trace how BI management has changed following the involvement of the second generation; and (iv) understand the decisions that the founder and the top management team have made over the years.

The interviews lasted between 40 and 108 minutes and were recorded and transcribed. We adopted the Gioia methodology for analysing the data and used NVivo10 software for the coding analysis (Gioia, Corley, and Hamilton, 2013). Starting with the quotations from the interviewees' and the derived concepts, five second-order themes (socialization processes; guaranteeing continuity to stakeholders; leveraging on the local geographical area; controlling key competences; cautiously exploring innovation) and two aggregate dimensions (processes aimed at preserving and processes aimed at adapting founder-based BI) were identified. Figure 1 represents the data structure, while Appendix I (Table 1) reports quotations of the first order concepts. 
Please insert Figure 1 about here

\section{Findings}

\subsection{Argenterie Giovanni Raspini s.p.a.: an overview}

Argenterie Giovanni Raspini s.p.a grew out of Arte Oro Arezzo, a small firm set up in 1972 in Arezzo (a city in Tuscany region, Italy), characterized by a unique silver production of small pendants (charms) and gold ornaments. At that time Giovanni Raspini's father was one of the investors, led by his passion for antiques and antique silverware. The same passion motivated Giovanni, who was working as an architect, to acquire $50 \%$ of the firm in 1985 , when Arte Oro Arezzo was facing a crisis. In 1993, following internal problems between Giovanni and the other owner, Giovanni acquired another $20 \%$ of the shares, while the remaining $30 \%$ were acquired by Claudio Arati: and so Argenterie Giovanni Raspini s.r.l. was founded.

Today the firm employees around 60 people, has 600 dealers, 13 flagship stores, and is located in 40 countries. Each new collection presents 200 new designs. Both Giovanni and Claudio still work in the firm, sharing ideas and making decisions together, with two very distinct, but interlinked tasks: design and production, respectively. Following a continuous growth, in the last decade the second generation has joined the firm. Costanza Raspini joined in 2012 and works full time as the marketing manager. Giannina Raspini and Elisa Arati joined more recently, working full time and part time respectively, in retail. 


\subsection{Emergence, Definition and Consolidation of Giovanni Raspini BI}

Three distinct phases can be identified in the creation of Argenterie Giovanni Raspini's BI (Figure 2).

Phase 1. The emergence of distinctive traits (1985-1993). The distinctive traits of Giovanni Raspini can be traced back to 1985, when Giovanni began to work for Arte Oro Arezzo, a firm operating in the jewellery district of Arezzo. As Claudio Arati, who was working for Arte Oro Arezzo at that time, remembers: "We made jewellery, in gold, for the Arab market. Our products were appreciated only by those countries. Arte Oro Arezzo had a clear market. Of course, it had to face various crises and at a certain point we began to made silver charms. They were enamelled charms or pure silver charms. And we had these two types of production."

Three main changes characterized the years following Giovanni's arrival in 1985: a shift from gold to silver production, a shift from jewels to household objects and silverware, but above all the animalier style adopted by Giovanni himself for the new creations. This animalier style was introduced to the firm by Giovanni and derives from his own creativity. A passion for silver, for the contrast between darkness and brightness, led Giovanni to identify the perfect subject and raw material for his creations in the skin of crocodiles, snakes and scorpions.

Phase 2: Defining a distinctive BI (1993-2008). In 1993 Giovanni and Claudio became the new owners of Arte Oro Arezzo and decided to change the name of the firm to Argenterie Giovanni Raspini s.r.l.

In those years, the firm grew gradually, but two main shifts characterized the BI dynamics. First, a change in distribution channels and the consequent change in communication and audience: the firm transitioned from wholesaler to retailer. This change influenced the way the 
brand was communicated. Giovanni wanted to transmit the value embedded in his products. A change in the way the brand was communicated was thus necessary: wholesalers were not able to fully communicate the richness of the product-related attributes, such as the uniqueness of the handicraft and the tradition linked to the local area. This change in distribution channels was new for Arezzo. Most firms, in fact, used wholesalers and this change was not understood by other silver manufacturers in the area. In reality, this represents one of the key successes for the firm. Through retailers, the firm was able to better communicate the value of the product as well as to transfer the nuances to the final users.

The second main shift was in terms of production. In the 1990s the firm mainly produced wedding gifts, frames, silverware, table and desk objects. These objects were promoted above all through specialist printed materials for bombonnière shops and top magazines for interior design such as $\mathrm{AD}$. The style used for these objects, and in particular the frames, was linked to naturalistic elements, such as butterflies and daisies. Toward the end of the 1990s, there was a shift towards silver jewellery. This shift was gradual and followed the changes in the market. Wedding gifts began to disappear due to societal changes, and Argenterie Giovanni Raspini increasingly made jewellery, introducing charms - small silver trinkets - as formerly produced by Arte Oro Arezzo.

Phase 3: Consolidating the BI (2009-now). At the end of the 2000s, pushed by this growing market demand, the firm moved from house ornaments to silver jewellery. Today, house ornaments and silverware represents $10 \%$ of the total sales, while wedding gifts have disappeared. All these objects are still characterized by a core identity relying on the style of Giovanni Raspini: “if you look for the leitmotif of our sparkling little creations, you'll see that it's the same singer singing, the same cook cooking, and the same painter painting", says Giovanni (La Gazette 29, 2010). 
The BI has been consolidated over these years thanks to a very careful and planned communication. It is worth mentioning the case of the second flagstore in Rome in via Margutta. Claudio Arati says:"The shop in Via Margutta is important because it will be a sort of trademark for us, in Italy and worldwide. Not only a selling outlet for our products, but above all, a microcosm able to truly represent us" (La Gazette, 28, 2009).

Please insert Figure 2 about here

\subsection{Managing a founder-based BI during succession}

We have summarized how the BI elements have evolved over time. Throughout the three phases, in fact, the founder-based BI has involved key, enduring attributes, while adjusting to the environmental context and adding new ones. Moving from Urde BI matrix (2013), below is a brief description of Giovanni Raspini identity elements (Figure 3).

Please insert Figure 3 about here

The core identity is linked to the promise and the core values of Giovanni Raspini: unique handcraft silver creations: Giovanni has been led by the "search for beauty" in every single creation, be it a jewel, a wedding gift, or a tray. 
The core identity is joined by the internal-external element of expression, which goes beyond the Giovanni Raspini logo and name (which has changed its visual aspect over time) and can be described in three elements. First, the founder style, characterized by the inspiration from the naturalistic world and imprinted on all the firm's creations. Second, the product-related attributes that derive from the tangible signs embedded in the products, related to the choice of silver: "silver belongs to our tradition. It is able to express brightness, it has high sculptural quality, it is precious and is protected by law. We have chosen to create silver jewels", says Giovanni. Third, the territory-related attributes. There is a long tradition in marketing research highlighting that place is important and represents a unique value (Charters, Spielmann and Babin, 2017). In Giovanni Raspini's jewels, there is a continuous use of a craftsmanship that derives from decades of experience and tradition and that is also linked to the local area as a blend of habits, traditions, behaviours and values.

A second internal-external element is the personality, characterized by a combination of attention to detail, hard-work, and respect on the part of all the employees. For example, one of the employees noted that the family has always paid attention to employees' needs.

In terms of the internal BI element, the firm's mission and vision merits highlighting. Giovanni wants to create a unique firm, capable of providing high quality products, retaining talent, and appreciating the concept of beauty. The culture is characterized by the sense of responsibility towards the local area, the importance of tradition, history and art, as well as the creation of a family working environment. Finally, in terms of competences, Giovanni Raspini is characterized by unique technical skills in using silver as well as design. With the advent of the second generation, this element has been enriched by marketing competences.

The external BI elements are represented by the value proposition: the uniqueness of handmade jewels or products at accessible prices. This element changed when the company decided to focus on jewels rather than wedding gifts. Second, the relationships with suppliers, 
distributors and customers, are characterized by trust and, especially with long-term suppliers,.

Finally, the intended position (positioning) is characterized by quality differentiation. When the firm creates its jewels, it aims to satisfy a specific audience: "when I think about one of our clients, I think about an autonomous woman, metropolitan, and who wishes to buy a piece of jewellery with its own strength, encumbrance and physicality.”, says Giovanni.

These elements represent the founder-based BI. The whole firm is aware of the need to consolidate its BI, especially since Giovanni is close to retirement. In Phases 1 and 2 the firm was completely run by Giovanni and Claudio with the help of key non-family managers who had worked for the firm since its foundation, however the consolidation phase (Phase 3) has seen the involvement of the second generation. In order to understand how this founder-based BI was managed during succession, the case revealed two key processes and five sub-processes.

\subsubsection{Processes aimed at preserving the enduring elements of the founder-based BI}

How can the enduring elements of a distinctive, enduring founder-based BI be preserved? The case suggests that Giovanni Raspini does it through:

(i) Socialization processes. The design of Giovanni Raspini's creations/products is strongly linked to the founder. He still represents the main source of creativity for the firm which is the most challenging resource to maintain over time since creativity is something that cannot be taught or transmitted. Since its foundation, the firmhas adopted two main mechanisms preserve its core attributes of design and craftsmanship.

First, the transmission of tacit knowledge linked to the founder-style is facilitated by socialization processes (Nonaka, 1994) with the founder and those employees dealing with the manufacture of Giovanni Raspini's creations. This facilitates the creation of a uniformity of style. All new objects share the same 'imprint', the same founder-style. Giovanni himself still designs his creations and also selects creations made by other team members. 
Second, the preservation and transmission of traditional techniques is facilitated by the fact that the FF is able to retain most of its employees. This ensures long-lasting relationships, facilitates the transmission of knowledge among employees and the creation of shared mental models which help in the production of the products.

(ii) Guaranteeing continuity to stakeholders. The firm has many relationships with its suppliers and its clients. These are maintained thanks to the exposure of the second generation to suppliers and clients. Hence, the founder-based BI endures the generational passage since a sense of continuity is guaranteed by the FF through two main ways.

First, learning-by-sharing: the second generation follows the first generation in order to understand the key elements characterizing the BI. They learn from the first generation in terms of how to behave and to be aligned with the specific 'style' of the founder-based BI. For example, the second generation participates in meetings, talks with the top management team, takes decisions having previously discussed them with the first generation. As a consequence, the same mental models are shared between the first and the second generations thanks to shared experiences and a continuity is guaranteed with respect to both internal and external stakeholders. As one of our interviewers says: “Costanza guarantees continuity from a product point of view, also from a creativity point of view. [...] The presence of Costanza guarantees this continuity and the participation in what I define as the core of the firm".

Second, the continuous dialogue with internal and external stakeholders enables the second generation to understand how the firm could improve. Since joining the firm, Costanza has been involved on a daily basis, communicating with other employees, understanding all the different marketing activities, and participating in the main strategic decisions with her father. The continuous dialogue with the other managers, with her father, and her careful interest in deciding what to retain and what to improve has enables the FF to make a resource inventory (Sirmon and Hitt, 2003). For example, a recent innovation introduced by Costanza - a small product card with 
the barcode - has enabled the product to be better communicated and, hence, has reinforced the BI. As she notes, her role is inter-functional and she intervenes where there is no-one with a clear responsibility over a specific problem. This small change, which was neither a logistical duty nor the responsibility of commercial director, has enabled the products to be promoted and sold in a uniform manner.

(iii) Leveraging on the territory. Territory is linked with the BI in four main ways. First, it represents a key complementary resource that the FF is able to leverage upon. Being located in the gold industrial district ${ }^{1}$ implies having an easier and quicker access to a series of tools that are needed by the firm in its daily activities. In addition, being a FF has enables the brand to ensure long lasting relationships with key suppliers. A nice example is that of three artisans who have complemented Claudio's productions for 20 years, sharing language and trust. Second, the FF is proactive with local institutions, such as the Municipal Gallery of Contemporary Art in Arezzo, and universities and professional schools. Third, the territory (i.e. the local area) in its form of "Made in Tuscany" is continuously promoted. For example, each issue of La Gazettethe house organ - contains one reference to the territory or to a key stakeholder in Tuscany. Finally, the family is involved in the promotion of the cultural heritage, supporting the arts, culture and creating ad hoc events.

\subsubsection{Processes aimed at the adaptation of the founder-based BI}

The case analysis highlights two key sub-processes involved in adapting the BI.

(iv) Controlling key competences. With the advent of the second generation and in order to facilitate its growth, the FF has chosen to reinforce its control over those activities that are thought of as strategic for the BI and to find complementary human resources in order to

\footnotetext{
${ }^{1}$ An industrial district is "a socio-territorial entity which is characterised by the active presence of both a community of people and a population of firms in one naturally and historically bounded area." (Becattini, 1992:38)
} 
juxtapose the growth. For example according to Costanza: "Retailing reinforces the image and identity. I manage orders, but I also carry out interviews personally with our shop assistants, with the architect I discuss the design of our shops, the exposition of our products".

A second key concern is developing competences. As Costanza says: "At a certain point, we realised that we needed a certain know-how in order to do things well. We have product knowhow, but we are weaker about how to sell it to the customers. We understood that, in order to go to the next level, we needed to acquire knowhow from outside. Hence, we looked for a retail director”.

(v) Cautiously exploring innovation. The FF addresses innovations in terms of both production and communication. While keeping its traditions, the FF has been able to adapt, to the increase in the price of the silver. Claudio remembers that a few years ago, the price of silver was so high that he introduced a new line made with "alpacca", i.e. German silver, creating the trademark BronzoBianco.

Second, communication is homogenous in terms of key messages, but is adapted in terms of the actual means. With the second generation new communication paths, such as social media, and new tools (such as Google trends), have been explored.

Third, the FF continues to imitate best practices regarding marketing taking inspiration from bigger firms.

\subsection{Preserve and adapt: a model for BI co-management during succession}

Firms tend to revise their BI over time and BI is usually co-created with customers (da Silveira et al., 2013). However, at Argenterie Giovanni Raspini s.p.a., this is not the case. BI is mainly orchestrated by the FF, thus suggesting that the BI in FFs is probably something that is mainly linked to and shaped by the family attributes, rather than led by customers. Three key roles 
emerge in the preservation of enduring founder-based BI attributes while adapting to external environmental conditions (e.g. changes in the price of raw materials, use of new communication channels): the founder, the second generation and non-family managers.

Figure 4 represents the model emerging from our case analysis, a self-reinforcing model for BI co-management over time. It adds to the resource-based view theory, showing the key processes needed to preserve and adapt the founder-based BI. These processes refine those of resource bundling and resource leveraging, as identified by Sirmon and Hitt (2003). According to these authors, FFs possess unique resources with respect to their non-family counterparts, but these are not sufficient for them to gain competitive advantage. These authors note that what really matters is how these resources are managed in relation to resource inventory, resource bundling, and resource leveraging.

Please insert Figure 4 about here

Our case shows that the founder-based BI is a key, unique resource resulting from human and social capital which are managed by the founder, the second generation, and non-family members alongside the two generations. The founder represents the "creative genius" who has no other way of transmitting his/her creativity apart from using socialization processes (Nonaka, 1994) which maintain the style that characterizes the Giovanni Raspini BI and to share the same values and culture with the second generation.

The second generation has a double role. First, it guarantees continuity with respect to both, internal and external stakeholders. Second, it is able to identify the areas of improvements to reinforce the founder-based BI and does this through a smooth innovation process: "I began 
analysing what was present, what was done, how to improve it step by step. Everything done within the marketing function were first done and understood by myself and only later delegated to others", says Costanza.

As research on FFs has noted, FFs are usually risk averse and tend not to introduce technological innovations. However, from our case two important insights emerge. When technological innovations are important in terms of better communicating the BI, they are easily adopted and implemented by the second generation. This suggests that future research should distinguish between the different scopes of technological innovations and the extent to which FFs tend to adopt them. Then, the FF needs to 'control' those complementary resources (i.e. human resources) which are synergic for the development of a stronger BI.

Finally, non-family managers, i.e. the external consultant and the commercial director, are work alongside the two generations in facilitating this transition. These actors also ensure the preservation as well as the adaptation of the BI.

\section{Conclusions}

This study has explored how a FF manages its BI during succession. We investigated how the involvement of the second generation has helped to preserve the enduring elements of the founder-based BI, while also adapting to environmental challenges. The case analysed provides a twofold contribution. On the one hand it adds to previous research on brand management (Brexendorf et al., 2015; Urde, 2013). It also refines the 'expression' of BI with three more elements, namely founder-style, product-related attributes and territory-related attributes. This stresses the need to carefully examine the key elements that could help firms in managing and building their BI. It also adds to the more recent call for research on FF branding (Binz Astrachan, Botero, Astrachan and Prügl, 2018; Beck 2016). 
Second the case contributes to research on FF resource management (Pucci et al., 2017; Sirmon and Hitt, 2003). Our findings suggest that founder-based BI is a unique resource in more traditional sectors, such as fashion, and highlights the juxtaposition between the first and second generations as well as non-family members in managing it (Churchill and Hatten, 1987). Our findings also highlight that managing a brand requires both a more static element -preserving the key BI enduring elements, such as style and the link with the local area - and a more dynamic element -adaptation to new environmental changes (e.g. new technologies and market prices). Our research suggests that in those firms whose BI is mainly linked to tacit knowledge and to one specific person who has multiple roles - founder, designer and father - a gradual juxtaposition of the second generation may help to ensure the preservation of the founder-based BI. This contributes to the research on succession (Royer, Simons, Boyd, and Rafferty, 2008) supporting the preference for family rather than non-family successors, but also provides initial support for the importance of having a proactive incumbent and proactive successor when incumbents are succession ready (Marler, Botero and De Massis 2016).

The paper also offers some valuable managerial implications. First, it suggests that the involvement of the second generation helps the firm to react faster to environmental changes. Second, distinguishing between core and supporting elements of BI enables marketing managers to better understand which elements of a firm's BI to preserve and/or adapt. Due to the heterogeneity of FFs, it would be interesting to understand to what extent and how these elements vary across generations when a new generation pursues different strategies.

Our study presents some limitations, typical of single case study research, such as lacking statistical generalizability and possessing a certain degree of subjectivity in interpreting the results (Gibbert et al. 2008). Consequently, future research could adopt a multiple case study design, analysing how family-based brand identities evolve over time following multiple generations. We only explored the case of "preserving and adapting", however it is likely that 
there are cases where the BI has been radically changed. Consequently, further research should investigate these cases. Moreover, we focused only on the jewellery market, which is a very particular context, characterized by different actors, new business models and different sources of competitive advantage (e.g. design competences and the brand). The case well describes the importance of handmade effects (Fuchs, Schreier, and van Osselaer 2015).

\section{Conflict of interest statement}

On behalf of all authors, the corresponding author states that there is no conflict of interest.

\section{References}

Aaker, D.A. (1996) Building strong brands. London: Simon \& Schuster, Free Press

Balmer, J. M. T. (2001) Corporate identity, corporate branding and corporate marketing Seeing through the fog. European Journal of Marketing 35(3/4): 248-291.

Balmer, J.M.T. and Burghausen, M. (2015) Explicating corporate heritage, corporate heritage brands and organizational heritage. Journal of Brand Management 22(5): 364-384.

Becattini, G. (1992) The Marshallian industrial district as a socio-economic notion. In F. Pyke, G. Becattini and W. Sengenberger (eds.) Industrial districts and inter-firm co-operation in Italy, Geneva: International Institute for Labour Studies, pp. 37-51.

Beck, S. (2016) Brand management research in family firms. Journal of Family Business Strategy 6(3): 225-250.

Binz Astrachan, C., Botero, I., Astrachan, J.H., Prügl, R. (2018) Branding the family firm: a review, integrative framework proposal, and research agenda. Journal of Family Business Strategy 9: 3-15. 
Binz, C., Hair, J.F. Jr., Pieper, T., and Baòdauf, A. (2013) Exploring the effect of distinct family reputation on consumers' preferences. Journal of Family Business Strategy 4: 3-11.

Bizri, R. (2016) Succession in the family business: drivers and pathways. International Journal of Entrepreneurial Behavior \& Research 22(1): 133-154.

Blombäck, A., and Ramírez- Pasillas, M. (2012) Exploring the logics of corporate brand identity formation. Corporate Communications: An International Journal 17(1): 7-28.

Botero, I.C., Thomas, J., Graves, C. and Fediuk, T.A. (2013) Understanding multiple family firm identities: and exploration of the communicated identity in official websites. Journal of Family Business Strategy 4: 12-21.

Brexendorf, T.O., Kernstock, J., and Powell, S.M. (2015) Future challenges and opportunities in brand management: an introduction to a commemorative special issue. Journal of Brand Management 21: 685-688.

Brockhaus, R. H. (2004) Family Business Succession: Suggestions for Future Research. Family Business Review 17(2): 165-177.

Brown, T.J., Dacin, P.A., Pratt, M.G., and Whetten, D.A. (2006) Identity, intended image, construed image, and reputation: an interdisciplinary framework and suggested terminology. Journal of the Academy of Marketing Science 34(2): 99-106.

Burghausen, M., and Balmer, J. M. T. (2014) Corporate heritage identity management and the multi-modal implementation of a corporate heritage identity. Journal of Business Research 67(11): 2311-2323.

Charters, S., Spielmann, N. and Babin, B.J. (2017) The nature and value of terroir products. European Journal of Marketing 51(4): 748-771.

Churchill, N. C., and Hatten, K. J. (1987) Non-market-based transfer of wealth and power: A research framework for family businesses. American Journal of Small Business 11(3): 5364. 
Cornelissen, J., Christensen, L. T., and Kinuthia, K. (2012) Corporate brands and identity: developing stronger theory and a call for shifting the debate. European Journal of Marketing 46(7/8): 1093-1102.

Cornelissen, J. P., Haslam, S. A., and Balmer, J. M. T. (2007) Social identity, organizational identity and corporate identity: Towards an integrated understanding of processes, patternings and products. British Journal of Management 18(SUPPL. 1): S1-S16.

Craig, J. B., Dibrell, C., and Davis, P. S. (2008) Leveraging Family Based Brand Identity to Enhance Firm Competitiveness and Performance in Family Businesses. Journal of Small Business Management 46(3): 351-371.

da Silveira, C., Lages, C., and Simões, C. (2013) Reconceptualizing brand identity in a dynamic environment. Journal of Business Research 66(1): 28-36.

de Chernatony, L. (1999) Brand Management Through Narrowing the Gap Between Brand Identity and Brand Reputation. Journal of Marketing Management 15(1-3): 157-179.

De Massis, A. and Kotlar, J. (2014) The case study method in family business research: Guidelines for qualitative scholarship. Journal of Family Business Strategy 5(1): 15-29.

Fox, M., Nilakant, V., and Hamilton, R. T. (1996) Managing Succession in Family-Owned Businesses. International Small Business Journal 15(1): 15-25.

Fuchs, C., Schreier, M., van Osselaer, S.M.J. (2015) The handmade effect: what's love got to do with it? Journal of Marketing 79: 98-110.

Gallucci, C., Santulli, R., and Calabrò, A. (2015). Does family involvement foster or hinder firm performance? The missing role of family-based branding strategies. Journal of Family Business Strategy 6(3): 155-165.

Gibbert, M., Ruigrok, W. and Wicki, B. (2008) What passes as a rigorous case study?. Strategic Management Journal 29: 1465-1474 
Gioia, D. A., Corley, K. G., and Hamilton, A. L. (2013) Seeking qualitative rigor in inductive research: notes on the Gioia Methodology. Organizational Research Methods 16: 15-31.

Hair, J.F. and Sarstedt, M. (2014) Innovative and established research methods in family business: description, illustration and application guidelines. Journal of Family Business Strategy 5: 1-3.

Handler, W. C. (1994) Succession in Family Business: A Review of the Research. Family Business Review 7(2): 133-157.

Hatch, M.J., and Schultz, M. (2001). Bringing the corporation into corporate branding. European Journal of Marketing 37(7/8): 1041-1064.

Hauck, J. and Prügl, R. (2015) Innovation activities during intra-family leadership succession in family firms: an empirical study from a socioemotional wealth perspective. Journal of Family Business Strategy 6(2): 104-118.

He, H., and Balmer, J. M. T. (2013) A grounded theory of the corporate identity and corporate strategy dynamic. European Journal of Marketing 47: 765-785.

Helin, J., and Jabri, M. (2016) Family business succession in dialogue: The case of differing backgrounds and views. International Small Business Journal 34(4): 487-505.

Iannone, F., and Izzo, F. (2017) Salvatore Ferragamo: An Italian heritage brand and its museum. Place Branding and Public Diplomacy 13(2): 163-175.

Kansikas, J., and Nemilentsev, M. (2010) Understanding family dynasty: Nurturing the corporate identity across generations. International Journal of Business Science and Applied Management 5(3): 32-42.

Kapferer, J.N. (2012) The new strategic brand management. Advanced insights and strategic thinking. $5^{\text {th }}$ ed. Paris: Les Editions d'Organization. 
Lansberg, I., and Astrachan, J. H. (1994) Influence of Family Relationships on Succession Planning and Training: The Importance of Mediating Factors. Family Business Review 7(1): 39-59.

Marler, L. E., Botero, I.C. and De Massis, A. (2016) Succession-related role transitions in family firms: the impact of proactive personality. Journal of Managerial Issues 29 (1): 57-81.

Melewar, T. C., Nguyen, B., Alwi, S. F. S., and Navare, J. (2017) Guest Editors' Introduction. Advancing the scholarship on corporate identity and corporate branding. International Studies of Management \& Organization 47(3): 217-219.

Micelotta, E. R., and Raynard, M. (2011) Concealing or Revealing the Family? Corporate Brand Identity Strategies in Family Firms. Family Business Review 24(3): 197-216.

Michel, G. (2017). From brand identity to polysemous brands: Commentary on "Performing identities: Processes of brand and stakeholder identity co-construction." Journal of Business Research 70: 453-455.

Muhonen, T., Hirvonen, S., and Laukkanen, T. (2017) SME brand identity: its components, and performance effects. Journal of Product \& Brand Management 26(1): 52-67.

Nonaka, I. (1994) A Dynamic Theory of Organizational Knowledge Creation. Organization Science 5(1): 14-37.

Presas, P., Muños, D., Guia, J. (2011) Branding familiness in tourism family firms. Journal of Brand Management 18(4/5): 274-284.

Pucci T., Brumana M., Minola T., and Zanni L. (2017) Social Capital and Innovation in a Life Science Cluster: The Role of Proximity and Family Involvement. The Journal of Technology Transfer. doi: 10.1007/s10961-017-9591-y

PwC (2017) The missing middle: bridging the strategy gap in US family firms. US family business $\quad$ survey. $\quad$ https://www.pwc.com/us/en/private-companyservices/publications/family-business-survey.html, accessed 6 November 2017. 
Royer, S., Simons, R., Boyd, B., and Rafferty, A. (2008) Promoting Family a Contingency Model of Family Business Succession. Family Business Review 21(1): 15-30.

Sirmon, D. G., and Hitt, M. A. (2003) Managing Resources: linking unique resources, management and wealth creation in family firms. Entrepreneurship Theory \& Practice: $339-359$.

Urde, M. (2013) The corporate brand identity matrix. Journal of Brand Management 20(9): 742761.

von Wallpach, S., Voyer, B., Kastanakis, M., and Mühlbacher, H. (2017) Co-creating stakeholder and brand identities: Introduction to the special section. Journal of Business Research 70: 395-398.

Wilson, S.R., Whitmoyer, J.G., Pieper, T.M., Astrachan, J.H., Hair, J.F. Jr., and Sarstedt, M. (2014) Method trends and method needs: examining methods needed for accelerating the field. Journal of Family Business Strategy 5: 4-14.

Yin, R. K. (2003) Case study research. Design and Methods. Thousand Oaks: SAGE Publications.

Zellweger, T. M., Eddleston, K. A., Kellermanns, F. W. (2010) Exploring the concept of familiness: Introducing family firm identity. Journal of Family Business Strategy 1(1): 5463.

Zellweger, T. M., Kellermanns, F. W., Eddleston, K. A., Memili, E. (2012) Building a family firm image: How family firms capitalize on their family ties. Journal of Family Business Strategy 3(4): 239-250. 
- Transmission of tacit knowledge linked to the founder-style

- $\quad$ Preservation and transmission of traditional techniques

- Learning-by-sharing by the second generation

- Continuous dialogue with other internal stakeholders

- $\quad$ Territory represents a key complementary resource

- $\quad$ Family is proactive with local institutions

- Territory as an element to be communicated

- Family involvement in the promotion of cultural heritage

- Reinforcing control over strategic key activities

- $\quad$ Find complementary HR

- Introduce innovations that do not break with tradition

- Innovate marketing smoothly, leveraging on new communication tools

- Imitating best practices from bigger firms in communication

Figure 1. Data Structure

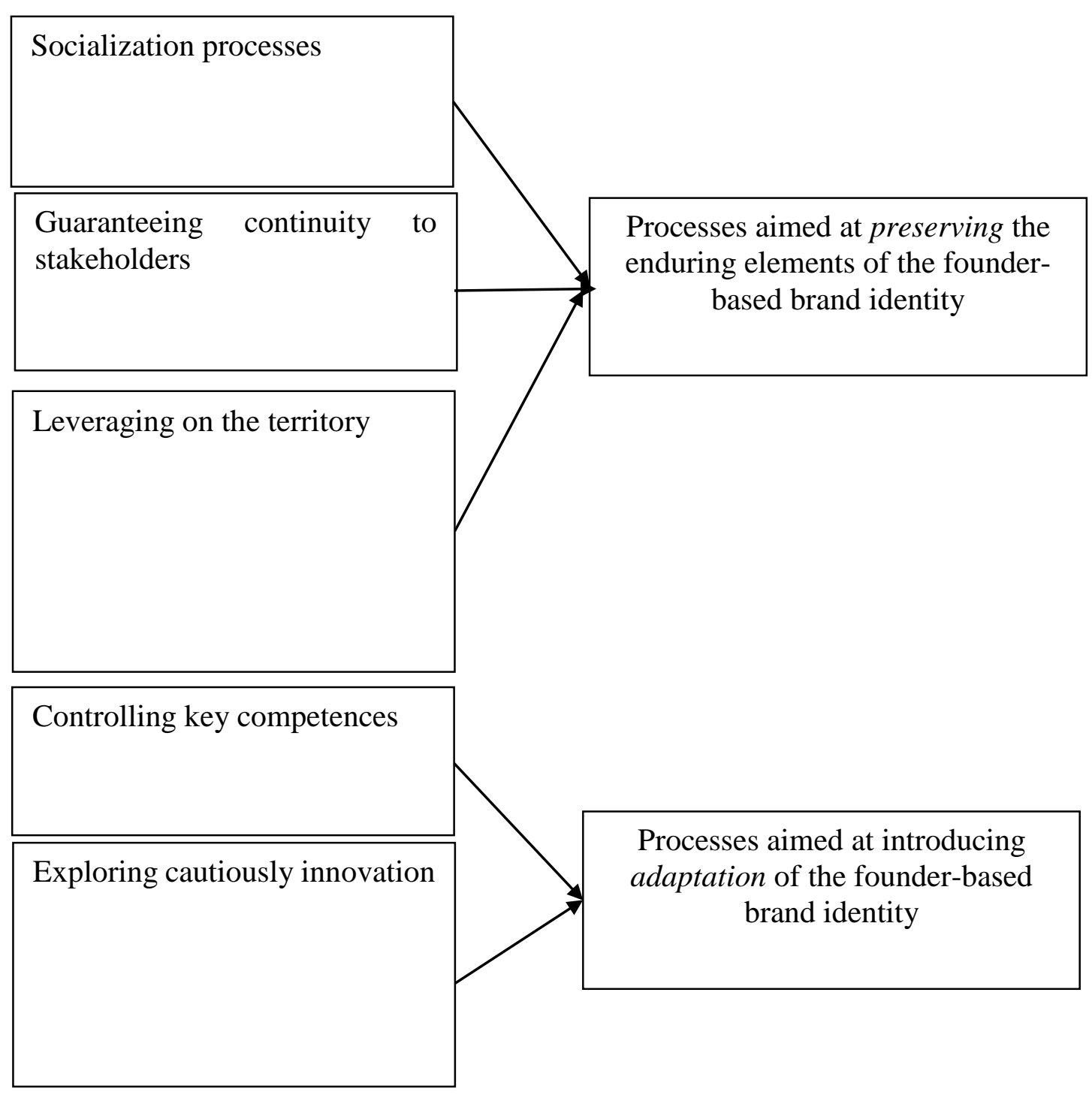




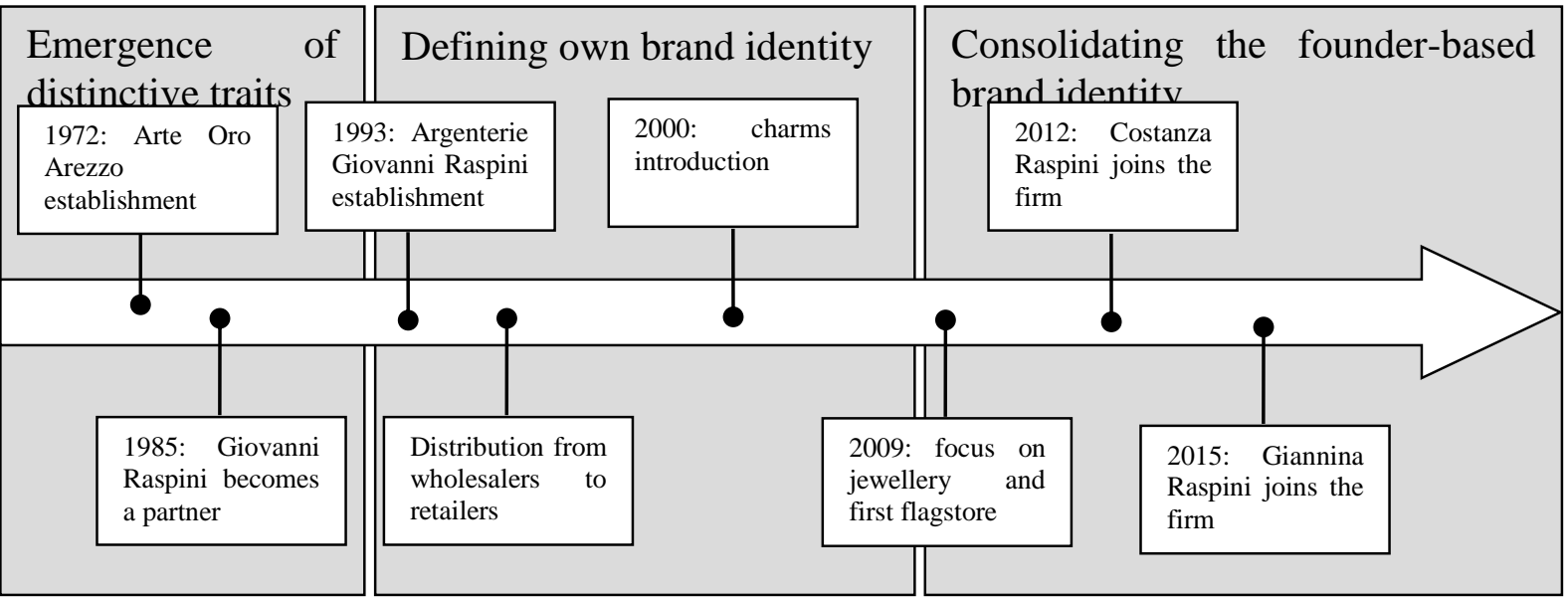

Figure 2. The evolution of Argenterie Giovanni Raspini 


\begin{tabular}{|c|c|c|c|c|c|c|c|c|}
\hline \multicolumn{3}{|c|}{ VALUE PROPOSITION } & \multicolumn{3}{|c|}{ RELATIONSHIP } & \multicolumn{3}{|c|}{ POSITION } \\
\hline Phase 1 & Phase 2 & Phase 3 & Phase 1 & Phase 2 & Phase 3 & Phase 1 & Phase 2 & Phase 3 \\
\hline $\begin{array}{l}\text { House objects } \\
\text { and silverware }\end{array}$ & $\begin{array}{l}\text { Introduction of } \\
\text { jewels }\end{array}$ & Focus on jewels & Arezzo district & $\begin{array}{l}\text { Long-term } \\
\text { relationships }\end{array}$ & $\begin{array}{l}\text { Customer } \\
\text { relationship } \\
\text { management }\end{array}$ & Wholesalers & $\begin{array}{c}\text { Wholesalers } \\
\text { Retailers } \\
\text { Quality } \\
\text { differentiation }\end{array}$ & $\begin{array}{c}\text { Flagship stores } \\
\text { Internationaziati } \\
\text { on } \\
\text { Multiple } \\
\text { segments }\end{array}$ \\
\hline \multicolumn{3}{|c|}{ EXPRESSION } & \multicolumn{3}{|c|}{ CORE } & \multicolumn{3}{|c|}{ PERSONALITY } \\
\hline $\begin{array}{c}\text { Stress the } \\
\text { product-related } \\
\text { attributes }\end{array}$ & $\begin{array}{c}\text { Brand name and } \\
\text { logo } \\
\text { Stress the } \\
\text { founder-style }\end{array}$ & $\begin{array}{l}\text { Stress the link } \\
\text { with the territory }\end{array}$ & Uniq & landcraft silve & ation & $\begin{array}{l}\text { Attention to } \\
\text { details } \\
\text { Hard-work } \\
\text { Respect }\end{array}$ & Solidarity & \\
\hline \multicolumn{3}{|c|}{ MISSION \& VISION } & \multicolumn{3}{|c|}{ CULTURE } & \multicolumn{3}{|c|}{ COMPETENCES } \\
\hline $\begin{array}{l}\text { High quality } \\
\text { products }\end{array}$ & $\begin{array}{c}\text { Valorising the } \\
\text { concept of } \\
\text { beauty }\end{array}$ & $\begin{array}{l}\text { Introduce trad- } \\
\text { innovation }\end{array}$ & Responsibility & $\begin{array}{l}\text { Focus on } \\
\text { tradition }\end{array}$ & $\begin{array}{l}\text { "Social" role of } \\
\text { the firm }\end{array}$ & $\begin{array}{c}\text { Design } \\
\text { Craftsmanship }\end{array}$ & Marketing & $\begin{array}{c}\text { Digital } \\
\text { Marketing }\end{array}$ \\
\hline
\end{tabular}

Figure 3. Brand identity matrix (adapted from Urde 2013) 


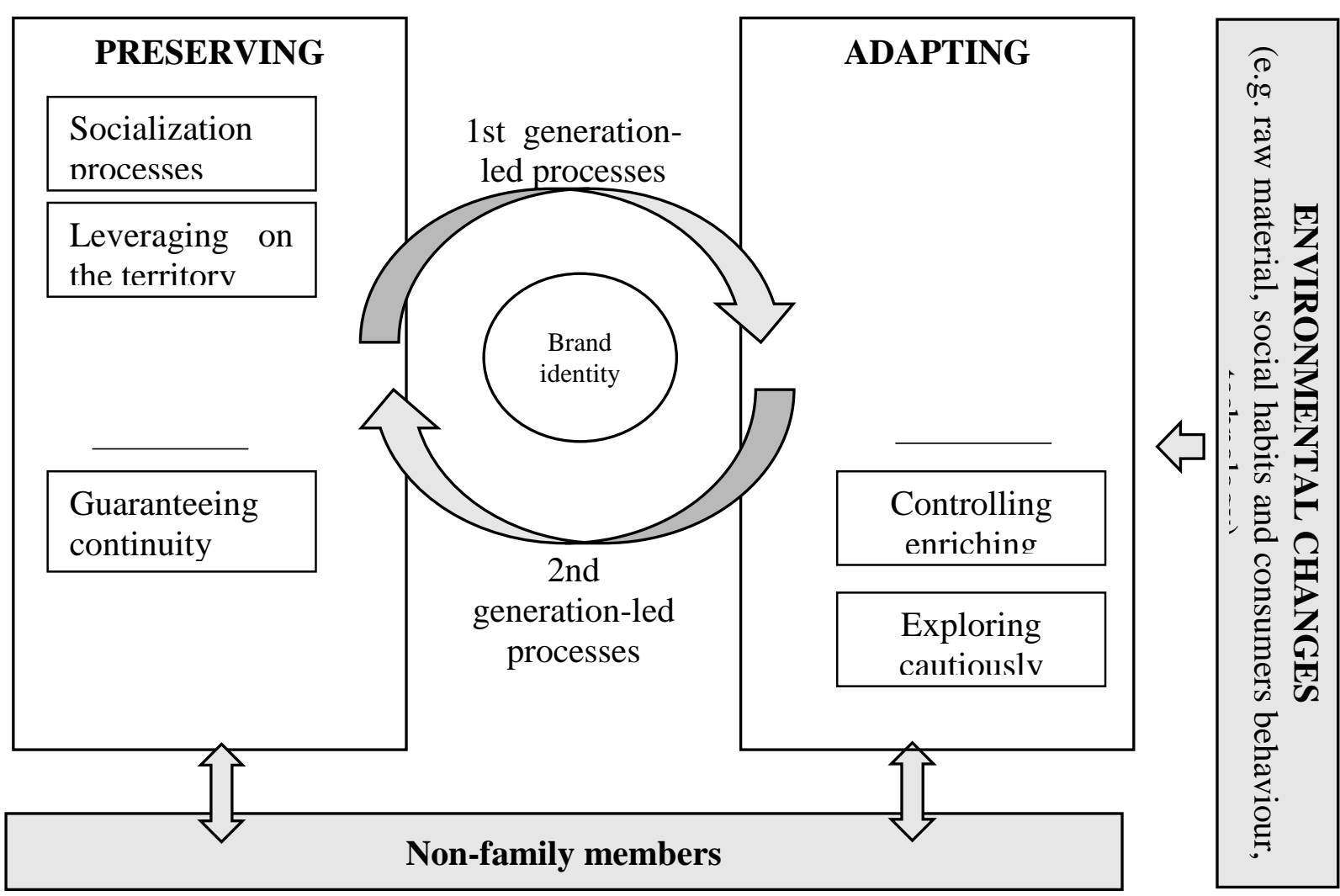

Figure 4. A model for brand identity co-management during succession 


\section{Appendix I}

\begin{tabular}{|c|c|}
\hline $\begin{array}{ll}2^{\text {nd }} & \text { order } \\
\text { themes } & \\
\end{array}$ & Representative quotations \\
\hline $\begin{array}{l}\text { Socialization } \\
\text { processes }\end{array}$ & $\begin{array}{l}\text { It is easy to perceive that in this firm we can sing several songs, but the } \\
\text { voice is always the same. This happens not because the singer - myself - } \\
\text { does everything by himself. At the end, due to the characteristics of our } \\
\text { production, due to the fact that we all work together as a group, what emerges } \\
\text { is the style of Giovanni Raspini brand. Its sign. (GR) } \\
\text { - I grew up with the firm and in the firm. [...]Thanks to Giovanni } \\
\text { Raspini's help and patience I have been able to optimize my hand-crafting } \\
\text { skills: designing, modelling and style awareness (nonfamily member 4, } \\
\text { Gazette } 29,2010 \text { ) }\end{array}$ \\
\hline $\begin{array}{l}\text { Guaranteeing } \\
\text { continuity to } \\
\text { stakeholders }\end{array}$ & $\begin{array}{l}\text { - We are preparing a departure. From a strategic point of view, this is } \\
\text { also understood by the market as an assurance of continuity with renewal } \\
\text { (nonfamily member } 2 \text { ) } \\
\text { - At a certain point, the objective of a firm like ours should be that of } \\
\text { getting rid of a specific person and arrive to a corporate identity deriving from } \\
\text { specific signs that are distinctive, continuous and unforgettable along time, } \\
\text { creating brand value (GR). } \\
\text { - The link with the family is perceived and cannot be dissolved } \\
\text { (nonfamily member 3) } \\
\text { - The identity is made by a sum of distinctive signs [...] For example the } \\
\text { word Giovanni Raspini is written with a specific font, not another one. This } \\
\text { is a sign as well as our angels face, our daisies. These are all part of a } \\
\text { multiplicity of signs that derive from choices made by me. At the moment I } \\
\text { am the coordinator, but in the future there should be coordinated by others } \\
\text { (GR) } \\
\text { - A firm like this welcome the family members with trust since these } \\
\text { persons represents the continuity (CR) }\end{array}$ \\
\hline $\begin{array}{l}\text { Leveraging } \\
\text { on the } \\
\text { territory }\end{array}$ & $\begin{array}{l}\text { - description of the processing stages on methods and techniques for } \\
\text { creating a model, the type of wax and lost-was casting, assembly stages, } \\
\text { soldering and polishing, assembly of finished parts, quality control and } \\
\text { packaging (nonfamily member 5, Gazette 30, 2010) } \\
\text { - "thanks to the Tuscan silversmith's passion, Arezzo University } \\
\text { receives in donation punches, hallmarks and documents on } 5 \text { centuries of } \\
\text { Italian gold work" (Gazette } 30,2010 \text { ) } \\
\text { - Mr. Luigi Berra, husband of Mrs. Laura Bausi, the last heir of A. Buasi } \\
\& \text { Sons, silversmiths in Florence, gave to Giovanni Raspini the silverware } \\
\text { designs, after the death of Mrs. Laura. There were donated by Giovanni } \\
\text { Raspini to Lab-Or, Centre for Studies on the history of goldsmith's design at } \\
\text { the Faculty of Letters of Siena University in Arezzo (Gazette 32, 2011) }\end{array}$ \\
\hline $\begin{array}{l}\text { Controlling } \\
\text { enriching } \\
\text { competencies }\end{array}$ & $\begin{array}{l}\text { - We acquire resources from outside, with a certain dynamics... we aim } \\
\text { at integrating the firm with what is missing, and the complementarity is the } \\
\text { soul that moves the firm. (nonfamily member } 2 \text { ) } \\
\text { - Trying to understand how everything works [Costanza is talking about } \\
\text { ecommerce] gives you results lowly, but allows you to control what you are } \\
\text { doing. (CR) } \\
\text { There are roots, there is the expertise... but other is the research. There } \\
\text { is a vivid ferment that has been implement during the last year. [...] For a }\end{array}$ \\
\hline
\end{tabular}




\begin{tabular}{|l|l|}
\hline & $\begin{array}{l}\text { couple of years, before building the team, before the team works, before the } \\
\text { souls begin to possess common links beyond individual fantasies... this is a } \\
\text { process. This is a complex process that needs different personalities that we } \\
\text { are selecting. (nonfamily member 2) }\end{array}$ \\
\hline $\begin{array}{l}\text { Exploring } \\
\text { cautiously } \\
\text { innovation }\end{array}$ & $\begin{array}{l}\text { internalize marketing functions } \\
\text { low outsourcing of the activities } \\
\text { not to do random experiments. We prefer to look at how new channels, new } \\
\text { means, etc. are used by other brand of our same sector. We look at those } \\
\text { brands that we judge superior. (CR) } \\
\text { Communication events are planned together by Giovanni and } \\
\text { Costanza. (nonfamily member) }\end{array}$ \\
\hline
\end{tabular}

Table 1. Representative quotations 